\title{
STRUCTURE AND PROPERTIES OF THE CARBURISED SURFACE LAYER ON 35CrSiMn5-5-4 STEEL AFTER NANOSTRUCTURIZATION TREATMENT
}

\author{
STRUKTURA IN LASTNOSTI NAOGLJIČENE POVRŠINE JEKLA \\ 35CrSiMn5-5-4 PO NANOSTRUKTURNI OBDELAVI
}

\author{
Emilia Skołek, Krzysztof Wasiak, Wiesław A. Świątnicki \\ Warsaw University of Technology, Faculty of Materials Science and Engineering, Wołoska 141, 02-507 Warsaw, Poland \\ emilia.skolek@nanostal.eu \\ Prejem rokopisa - received: 2014-10-08; sprejem za objavo - accepted for publication: 2014-12-09
}

doi:10.17222/mit.2014.255

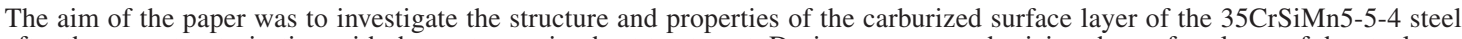
after the nanostructurisation with the austempering heat treatment. During vacuum carburizing the surface layer of the steel was enriched with carbon above $w=0.6 \%$. Steel samples were subsequently austenitized, quenched at two different temperatures, $260{ }^{\circ} \mathrm{C}$ and $320^{\circ} \mathrm{C}$, and annealed at these temperatures for the time necessary for the completion of the bainitic transformation. For comparison, one set of carbonized samples was subjected to the conventional heat treatment: martensitic quenching and low tempering. The microstructural characterisation of the steel after different heat treatments was performed using scanning (SEM) and transmission (TEM) electron microscopes. It was shown that both austempering treatments led to a carbide-free nano-bainitic structure composed of nanometric ferrite plates separated by thin layers of retained austenite. The microhardness and wear resistance of three kinds of steel samples were investigated: the two subjected to the austempering treatment at different temperatures and the one subjected to the conventional treatment. It was shown that the nano-bainitic structure containing an increased amount of retained austenite displays a higher wear resistance than the tempered martensite. The results confirm that austempering can be a competitive method of thermal treatment, in comparison to the conventional heat treatment, for the steels after the carburizing process.

Keywords: vacuum carburizing treatment, carburized surface layer, carbide-free bainite, austempering, wear resistance
\end{abstract}

Namen tega dela je preiskati strukturo in lastnosti naogljičene površine jekla 35CrSiMn5-5-4 po nanostrukturiranju s toplotno obdelavo austempranja. Med naogljičenjem v vakuumu se je površina jekla obogatila $\mathrm{z}$ ogljikom nad masnim deležem $w=0,6$ $\%$. Vzorci jekla so bili segreti v avstenitno področje, gašeni na dve različni temperaturi: $260{ }^{\circ} \mathrm{C}$ in $320{ }^{\circ} \mathrm{C}$, in zadržani na teh temperaturah, potrebnih za popolno bainitno pretvorbo. Za primerjavo je bila serija naogljičenih vzorcev toplotno obdelana po navadni metodi: gašenje $\mathrm{v}$ martenzit in popuščano pri nizki temperaturi. Karakterizacija mikrostrukture jekla po različnih toplotnih obdelavah je bila izvršena z vrstičnim (SEM) in presevnim (TEM) elektronskim mikroskopom. Izkazalo se je, da obe toplotni obdelavi austempranja povzročita nastanek nanobainitne strukture brez karbidov in sestavljene iz nanometrskih feritnih ploščic, ločenih s tanko plastjo zaostalega avstenita. Pri treh različnih vzorcih je bila izmerjena mikrotrdota in odpornost proti obrabi; pri dveh $\mathrm{z}$ austempranjem pri različnih temperaturah in enem $\mathrm{z}$ navadno toplotno obdelavo. Izkazalo se je, da ima nanobainitna struktura s povečanim deležem zaostalega avstenita večjo odpornost proti obrabi kot pa popuščeni martenzit. Rezultati so potrdili, da je toplotna obdelava $\mathrm{z}$ austempranjem boljša metoda toplotne obdelave kot navadna toplotna obdelava za jekla po postopku naogljičenja.

Ključne besede: naogljičenje v vakuumu, naogljičena plast, bainit brez karbidov, austempranje, odpornost proti obrabi

\section{INTRODUCTION}

Carbide-free bainite obtained in the bottom range of bainitic transformation is characterised by exceptionally high mechanical properties such as hardness and tensile strength. ${ }^{1-5}$ Moreover, its ductility is kept due to a high volume fraction of the retained austenite. ${ }^{5-7}$ Simultaneously, a lack of cementite precipitations as well as the presence of a great amount of the retained austenite in the form of thin layers placed between the bainitic plates, result in a high fracture toughness. ${ }^{89}$ The presence of the retained austenite may also increase the frictional wear resistance. ${ }^{10,11}$ It was postulated ${ }^{10-12}$ that during the wear tests austenite may transform into the strain-induced martensite due to the stresses occurring during the friction. This would increase the hardness in the contact zone as well as the frictional wear resistance in comparison to the samples containing tempered martensite after the conventional treatment. ${ }^{10-12}$

Initially, the carbide-free structure was produced in the types of steel with specifically designed chemical compositions. These contained the appropriate amounts of carbon, silicon and manganese. ${ }^{13}$ However, recently an attempt was made to obtain such a structure also in the commercial types of steel. ${ }^{5,14,15}$ The main objective of the present study was to produce a structure of carbide-free bainite in the surface layer of the 35CrSiMn5-5-4 steel after the carburising. The second objective was to determine the effect of the isothermal-quenching temperature on the structure and the surface properties of the examined material. 


\section{EXPERIMENTAL PROCEDURE}

\subsection{Vacuum carburizing}

The carburizing process was carried out in a 15.0 VPT-4022/24N vacuum furnace at the Seco/Warwick Company. The carburizing treatment was conducted with the FineCarb® technology in accordance with the patent. ${ }^{16}$ It was divided into ten subsequent processes of saturation and diffusion. The times of particular saturation and diffusion processes were selected in accordance with the simulations conducted with the SimVaC Plus ${ }^{\circledR}$ programme. The carburising atmosphere was a mixture of acetylene, ethylene and hydrogen. Due to the possibility of a significant growth of austenite grains, the pearlitisation process was carried out directly after the carburisation process. Afterwards, the furnace feed was heated up to $850{ }^{\circ} \mathrm{C}$, held for $20 \mathrm{~min}$ and, finally, slowly cooled to the room temperature at the furnace-cooling rate.

\subsection{Carbon-content measurements}

The amount of carbon after the carburisation process was determined on the cross-section of the layer, using the Magellan Q8 Bruker optical emission spectrometer with spark excitation. The study was conducted from the front of the sample. 21 measurements were carried out at $0.1 \mathrm{~mm}$ - a surface layer of about $0.1 \mathrm{~mm}$ was removed after each measurement to obtain the cross-section of the carbon content. The measurements were performed in an accredited laboratory, in accordance with the 3/CHEM procedure, 3 ed., Sep 2010, with a precision of $0.02 \%$ (0.001\% for sulphur and phosphorus).

\subsection{Heat treatment}

In order to form a nano-bainitic microstructure, the carburised samples of steel were austenitized for $30 \mathrm{~min}$

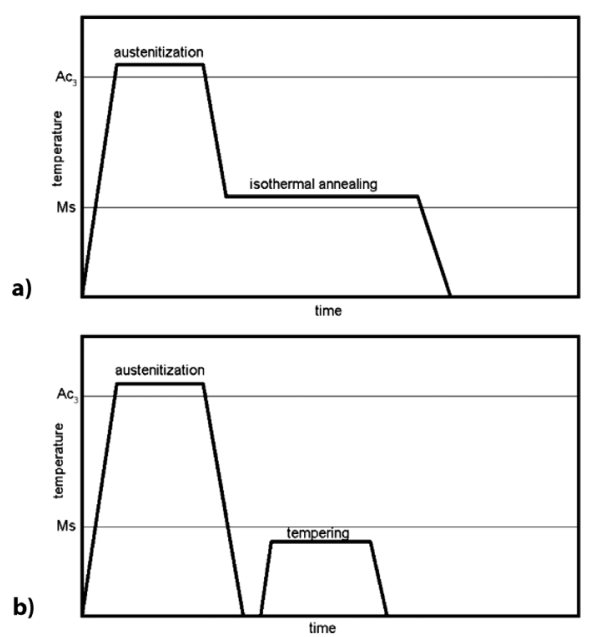

Figure 1: a) Scheme of the austempering and b) quenching and lowtempering treatment

Slika 1: Shematski prikaz toplotne obdelave: a) austempranje, b) gašenje in popuščanje pri nižji temperaturi at a temperature of $900{ }^{\circ} \mathrm{C}$, then cooled to the temperature range of the bainitic transformation and, finally, annealed at this temperature (Figure 1). The cooling medium used for isothermal quenching was composed of a liquid alloy of $\mathrm{Sn}-\mathrm{Ag}$ heated up to the temperature of the isothermal step $\left(260{ }^{\circ} \mathrm{C}\right.$ and $\left.320^{\circ} \mathrm{C}\right)$. The time of isothermal quenching was selected in the way that ensured the end of the bainitic transformation at the temperature of isothermal annealing. The conventional heat treatment consisting of the martensitic quenching from the temperature of $900{ }^{\circ} \mathrm{C}$ and the subsequent tempering process at a temperature of $200{ }^{\circ} \mathrm{C}$ for $1 \mathrm{~h}$ was performed in order to compare the properties of the layers obtained with two treatments. In this case, the oil quenching (WODOL) intended for structural steels was used as a cooling medium.

\subsection{Microstructural observations}

The microstructures of the austempered samples were examined with the use of light microscopy, SEM Hitachi S-3500N scanning electron microscopy and the TEM JEOL 1200 transmission electron microscope working at $120 \mathrm{kV}$. The LM and SEM observations were conducted just under the surface of the layer. At first, 50 $\mu \mathrm{m}$ of the examined material of the sample surface were grinded. Subsequently, the surfaces were etched with the Nital agent. The TEM observations were conducted at the surface zone of the layers at a depth of about 50-100 $\mu \mathrm{m}$ from the surface and in the core of the samples. Thin plates with a thickness of $200 \mu \mathrm{m}$ were cut out of the samples, grinded to a thickness of $100 \mu \mathrm{m}$ and, finally, electrolytically polished until perforation occurred. Phase constituents were identified according to the images of the electron diffraction analysis. The observations were carried out both in the bright field (BF) and in the dark field (DF), using the reflexions obtained from different phases.

The thickness of the ferrite plates and the austenite layers, observed on the TEM images, was determined in accordance with the following stereological Equation: ${ }^{17}$

$$
d=\frac{2}{\pi} L
$$

where $d$ stands for the real size of the element of the microstructure (in the analysed case, the real thickness of a plate) and $L$ means the size of the microstructure measured on the TEM image (in this case, the width measured on the image). The plate widths $(L)$ were measured perpendicularly to the interphase boundaries.

The relative volume fraction of the phases was calculated on the assumption that the volume fraction of a given phase is equivalent to its area fraction observed on the image. Therefore, the n numbers of the secants of the $l$ length were marked on the image of the microstructure. The volume fractions of phases $V_{\mathrm{V}}$ were calculated with the following formula: 
Table 1: Chemical composition of the 35CrSiMn5-5-4 steel in mass fractions, $w / \%$

Tabela 1: Kemijska sestava jekla 35CrSiMn5-5-4 v masnih deležih, w/\%

\begin{tabular}{|c|c|c|c|c|c|c|c|c|c|c|}
\hline & C & $\mathrm{Cr}$ & Mn & Si & $\mathbf{N i}$ & $\mathrm{Cu}$ & Al & Mo & $\mathbf{W}$ & $\mathrm{Fe}$ \\
\hline$w / \%$ & 0.35 & 1.31 & 0.95 & 1.3 & 0.14 & 0.15 & 0.04 & 0.018 & $<0.03$ & balance \\
\hline
\end{tabular}

$$
V_{v}=\frac{\sum c_{i k}}{n l}
$$

where $\Sigma c_{i k}$ is the sum of the widths of all the intersections of the secant line $l$ with a given phase, $l-$ the length of the secant line.

\subsection{Microhardness measurements}

The measurements of the microhardness on the intersection of a layer were conducted with a LECO LM 248AT semi-automatic microhardness tester with the AMH43 v1.81 software in accordance with the PN-EN ISO 6507-1 norm. ${ }^{18} 1.96 \mathrm{~N}$ and $9.81 \mathrm{~N}$ loads, indenting the material for $10 \mathrm{~s}$, were used in the investigation.

\subsection{Wear-resistance measurements}

The wear resistance measurements were carried out with the block-on-ring method using a T-05 tester, in conformity with the ASTM G77 norm. ${ }^{19}$ The examined sample was of a block shape and a width of $6.35 \mathrm{~mm}$. The ring with an outer diameter of $34.99 \mathrm{~mm}$ was used as a counter specimen. The ring used in the research was made of the $100 \mathrm{Cr} 6$ bearing steel with a hardness of 62 HRC. The investigation lasted for $100 \mathrm{~min}$ and the applied unit load was $200 \mathrm{~N} \mathrm{~mm}^{-2}$ and $400 \mathrm{~N} \mathrm{~mm}^{-2}$. The rotation speed was $316 \mathrm{r} / \mathrm{min}(5.26 \mathrm{~Hz})$ and the rubbing speed was $0.25 \mathrm{~m} / \mathrm{s}$. The track of the wear radius was $17.5 \mathrm{~mm}$. Lux 10 oil was used as the grease.

\section{RESULTS AND DISCUSSION}

The previous research conducted on the 35CrSiMn5-5-4 steel indicated that the formation of carbide-free bainite structure with nanometric or submicron grain sizes can be achieved during isothermal quench-

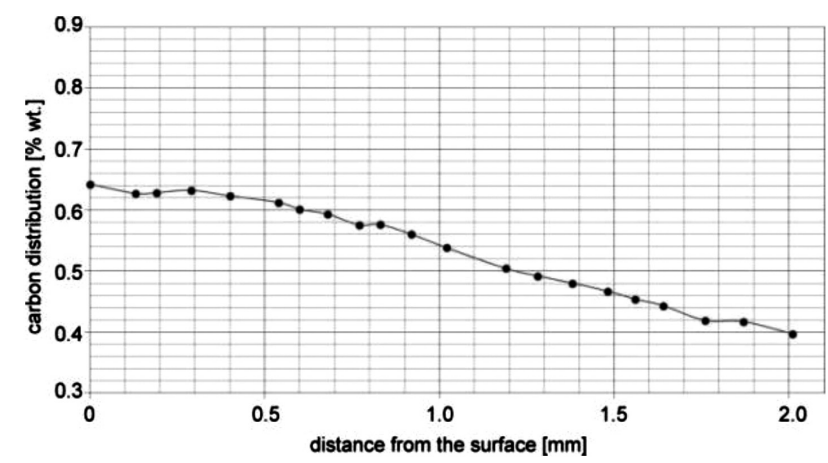

Figure 2: Carbon-content profile for the carburized surface layer on 35CrSiMn5-5-4 steel

Slika 2: Profil vsebnosti ogljika v naogljičeni plasti na jeklu 35CrSiMn5-5-4 ing. ${ }^{15}$ However, the amount of the retained austenite is relatively low due to a relatively low carbon content is this steel..$^{15}$ In order to increase the carbon content in the surface layer, the 35CrSiMn5-5-4 steel with the chemical composition presented in Table 1 was submitted to the vacuum carburizing treatment using the injection method. The increase in the carbon content facilitated the formation of a nano-bainitic structure in the steel.

The analysis of the chemical composition of the cross-section of the carburised layer of a steel sample indicated that the carbon content at the surface is $w=$ $0.64 \%$. This value remains constant up to a depth of 0.5 $\mathrm{mm}$ from the surface. At a depth of $2 \mathrm{~mm}$ the carbon content is $w=0.39 \%$ (Figure 2).

A fine-grained acicular structure was formed during the isothermal quenching at the temperature of $260{ }^{\circ} \mathrm{C}$, in the carburised layer of steel. The bainitic ferrite plates within this structure were either parallel to each other or arranged at different angles to each other. They formed groups or packages. An increase in the temperature of the treatment resulted in the microstructure in which small, unetched areas of the retained austenite occurred,
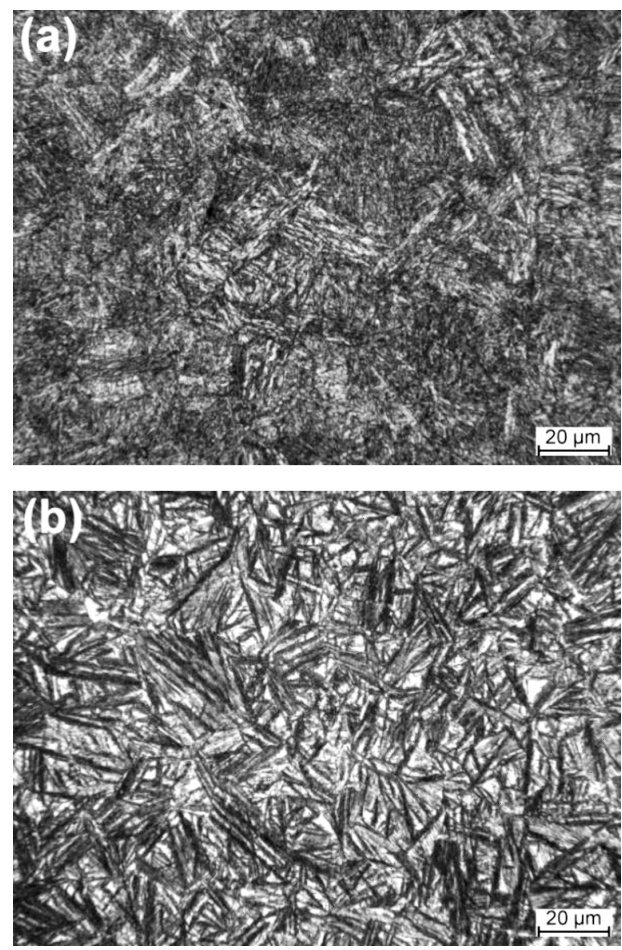

Figure 3: Microstructure of the carburized surface layer on 35CrSiMn5-5-4 steel after austempering at: a) $260{ }^{\circ} \mathrm{C}$ and b) $320{ }^{\circ} \mathrm{C}-$ LM images

Slika 3: Mikrostruktura naogljičene površine jekla 35CrSiMn5-5-4 po austempranju na temperaturi: a) $260{ }^{\circ} \mathrm{C}$ in b) $320^{\circ} \mathrm{C}$ (svetlobna mikroskopija) 

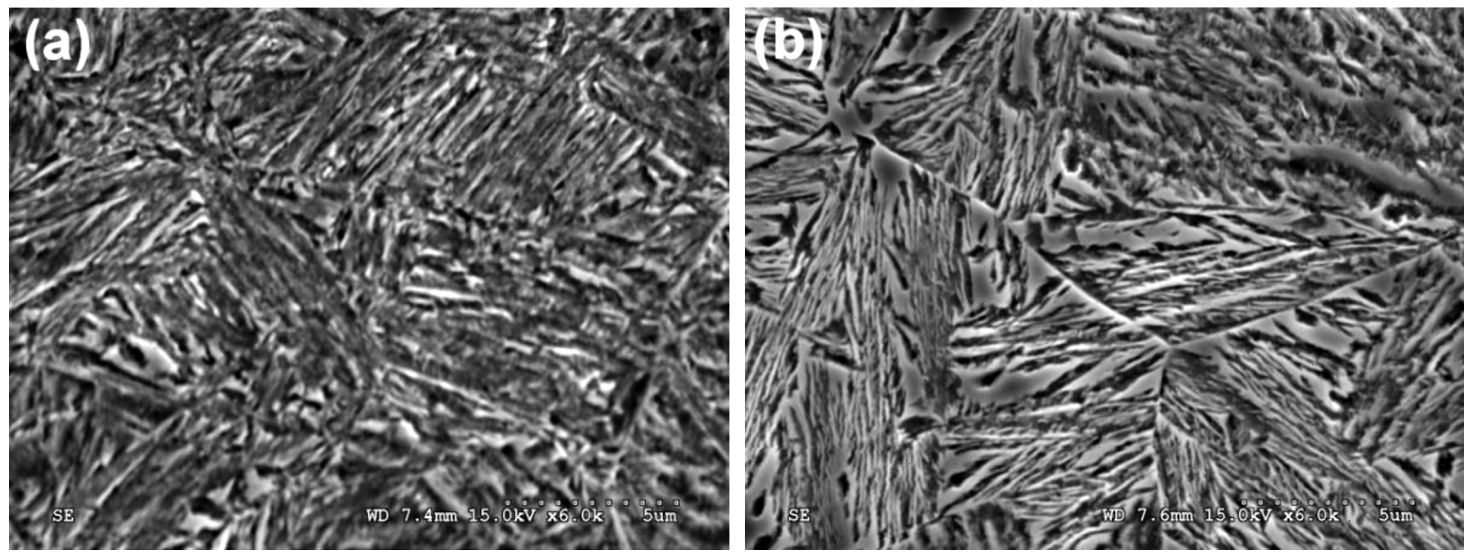

Figure 4: Microstructure of the carburized surface layer on $35 \mathrm{CrSiMn} 5-5-4$ steel after austempering at: a) $260{ }^{\circ} \mathrm{C}$ and b) $320{ }^{\circ} \mathrm{C}-\mathrm{SEM}$ images Slika 4: Mikrostruktura naogljičene plasti jekla $35 \mathrm{CrSiMn} 5-5-4$ po austempranju na temperaturi: a) $260{ }^{\circ} \mathrm{C}$ in b) $320{ }^{\circ} \mathrm{C}$ (SEM-posnetka)
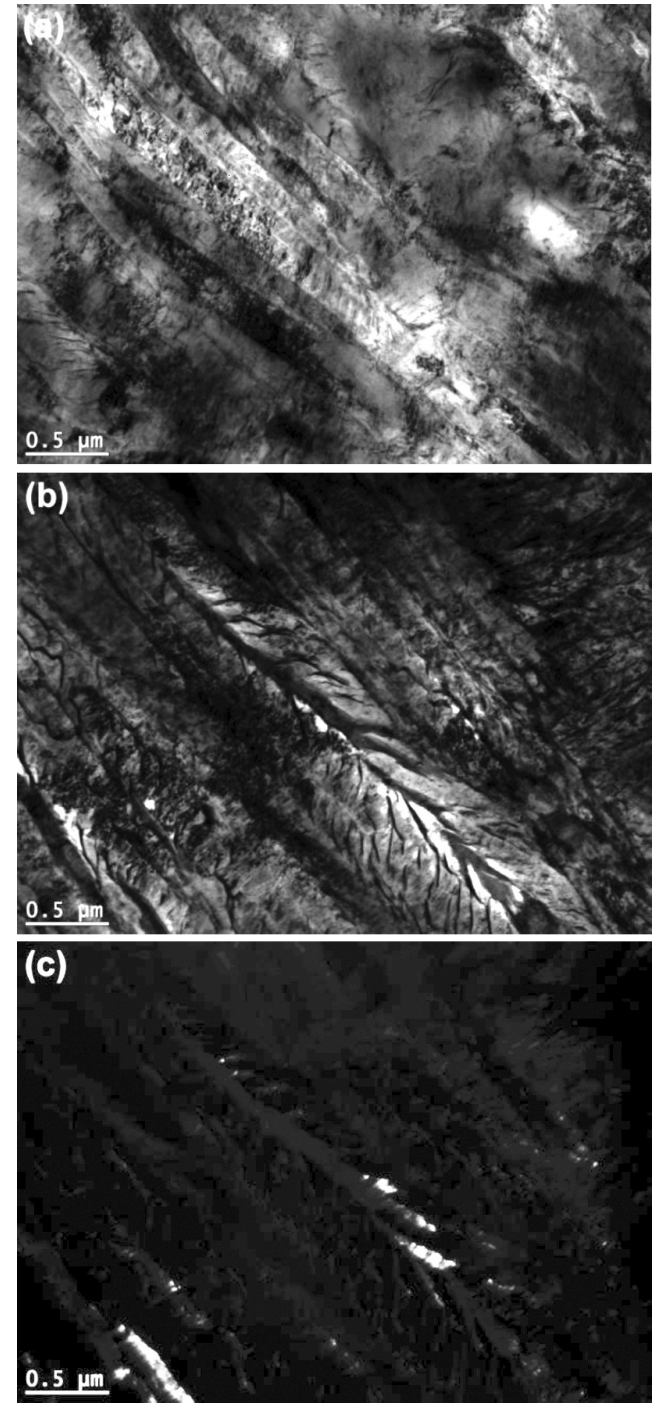

Figure 5: a) Microstructure of the carburized surface layer on $35 \mathrm{CrSiMn} 5-5-4$ steel after austempering at $260^{\circ} \mathrm{C}$, b) TEM BF image, c) TEM DF image of austenite reflection

Slika 5: a) Mikrostruktura naogljičene plasti na jeklu 35CrSiMn5-5-4 po austempranju na temperaturi $260{ }^{\circ} \mathrm{C}$, b) TEM BF-posnetek, c) TEM DF-posnetek odboja avstenita apart from the fine bainite plates arranged parallelly to each other (Figures 3 and 4).

A detailed investigation, conducted with TEM, of the microstructure of a steel sample treated at the temperature of $260{ }^{\circ} \mathrm{C}$ revealed the presence of martensite and carbide-free nano-bainite. The martensite and bainite were separated from each other with the layers of retained austenite (Figure 5). The average measured width of the ferritic and martensitic plates was $(102 \pm 7) \mathrm{nm}$, whereas the width of the layers of the retained austenite was $(33 \pm 3) \mathrm{nm}$. The increase in the temperature of the
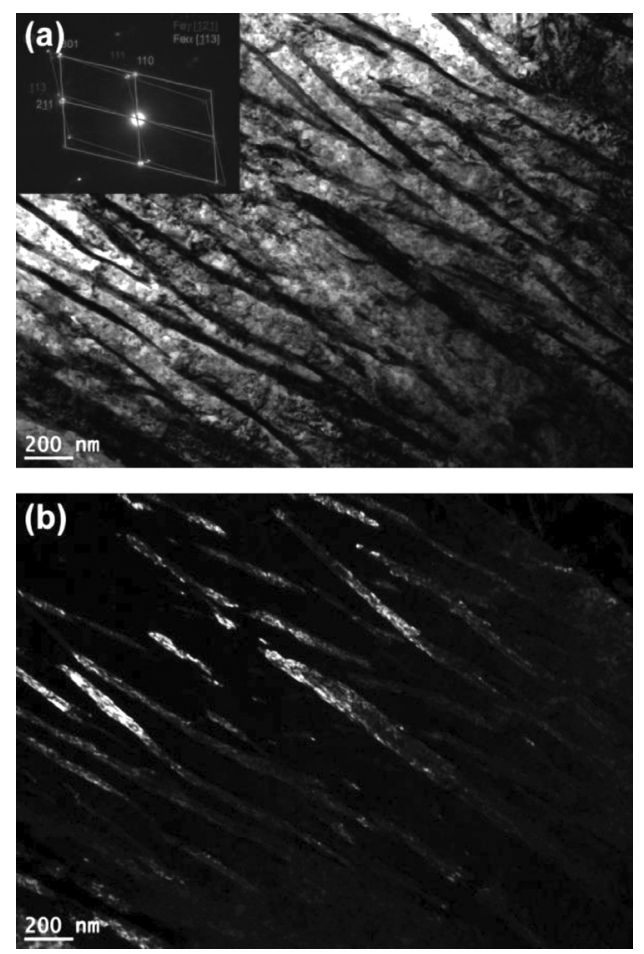

Figure 6: Microstructure of the carburized surface layer on 35CrSiMn5-5-4 steel after austempering at $320^{\circ} \mathrm{C}$ : a) TEM BF image, b) TEM DF image of austenite reflection

Slika 6: Mikrostruktura naogljičene površine jekla $35 \mathrm{CrSiMn5-5-4}$ po austempranju na $320^{\circ} \mathrm{C}$ : a) TEM BF-posnetek, b) TEM DF-posnetek odboja avstenita 


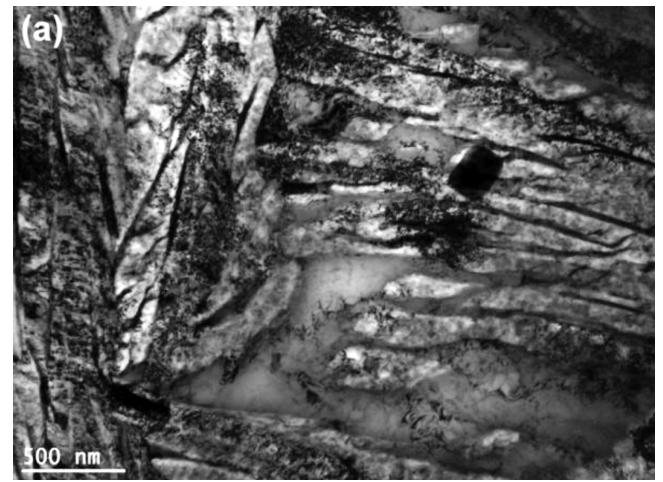

Figure 7: Block of retained austenite in the carburized surface layer on $35 \mathrm{CrSiMn} 5-5-4$ steel after austempering at $320^{\circ} \mathrm{C}$

Slika 7: Kos zaostalega avstenita v naogljičeni površini jekla $35 \mathrm{CrSiMn5-5-4}$ po austempranju na $320{ }^{\circ} \mathrm{C}$

treatment to $320^{\circ} \mathrm{C}$ allowed the formation of a structure consisting of carbide-free bainite with the retained austenite. The bainitic plates have the average width of $65 \mathrm{~nm}$ $\pm 4 \mathrm{~nm}$, whereas the layers of the retained austenite are $26 \mathrm{~nm} \pm 2 \mathrm{~nm}$ thick (Figure 6). Additionally, blocks of austenite with an area not exceeding $1 \mu^{2}$ were observed (Figure 7).

The relative volume fraction of the retained austenite in the surface layer, estimated on the basis of the TEM images was $(20.5 \pm 3.5) \%$ and $(20.2 \pm 3.5) \%$ for the samples isothermally quenched at $260{ }^{\circ} \mathrm{C}$ and $320{ }^{\circ} \mathrm{C}$, respectively. The microstructure obtained through isothermal quenching at $320{ }^{\circ} \mathrm{C}$ was relatively homogenous
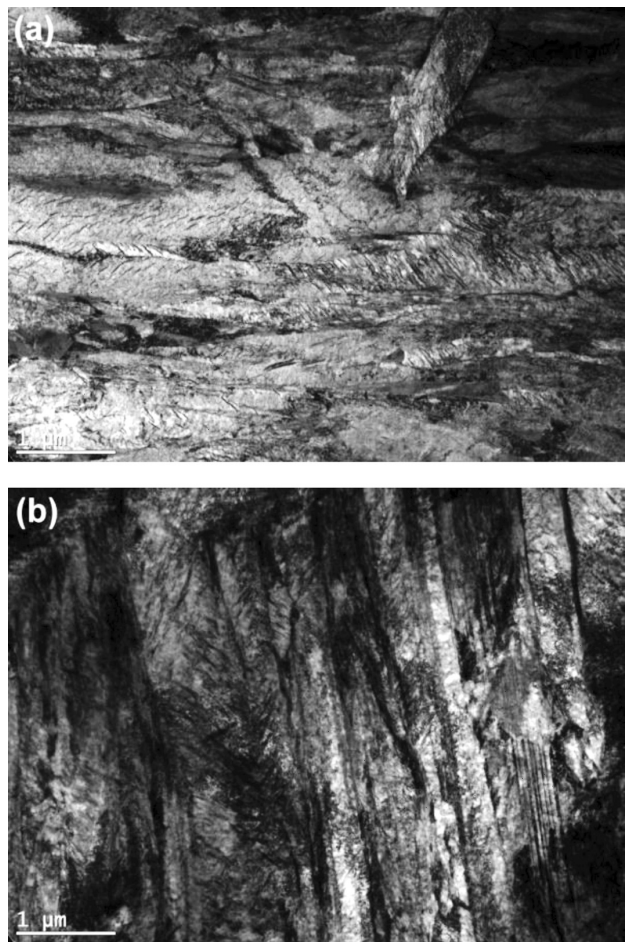

Figure 8: Microstructure of the core of the carburized steel after austempering at $260{ }^{\circ} \mathrm{C}$

Slika 8: Mikrostruktura jedra pri naogljičenem jeklu po austempranju na $260{ }^{\circ} \mathrm{C}$

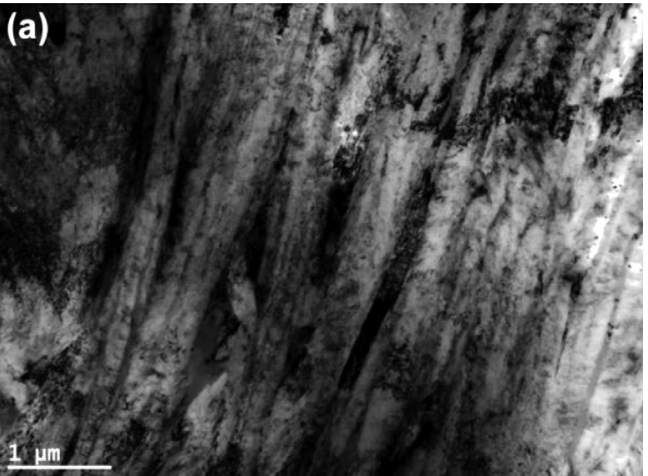

Figure 9: Microstructure of the core of the carburized steel after austempering at $320{ }^{\circ} \mathrm{C}$

Slika 9: Mikrostruktura jedra pri naogljičenem jeklu po austempranju na $320{ }^{\circ} \mathrm{C}$

in terms of the grain size. However, areas with different amounts of austenite were observed in the structure, as well as some individual secondary carbides that did not form clusters.

In the cores of the samples treated at $260{ }^{\circ} \mathrm{C}$ a martensitic-bainitic structure was formed. The presence of martensite resulted from the $M$ s temperature of $307{ }^{\circ} \mathrm{C}$ which is higher than the austempering temperature. The presence of highly dense carbides in martensite laths indicates that the tempering process occurred in the core of a sample during the austempering (Figure 8). The
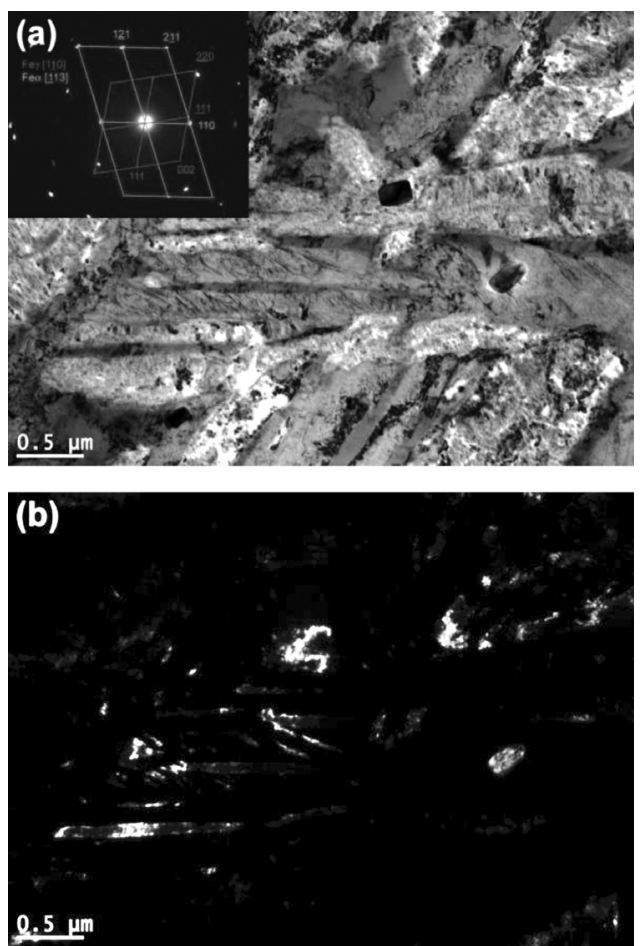

Figure 10: Austenite areas in the core of the carburized steel after austempering at $320^{\circ} \mathrm{C}$ : a) TEM BF image, b) TEM DF image of austenite reflection

Slika 10: Avstenitna področja v jedru pri naogljičenem jeklu po austempranju na $320{ }^{\circ} \mathrm{C}$ : a) TEM BF-posnetek, b) TEM DF-posnetek odboja avstenita 

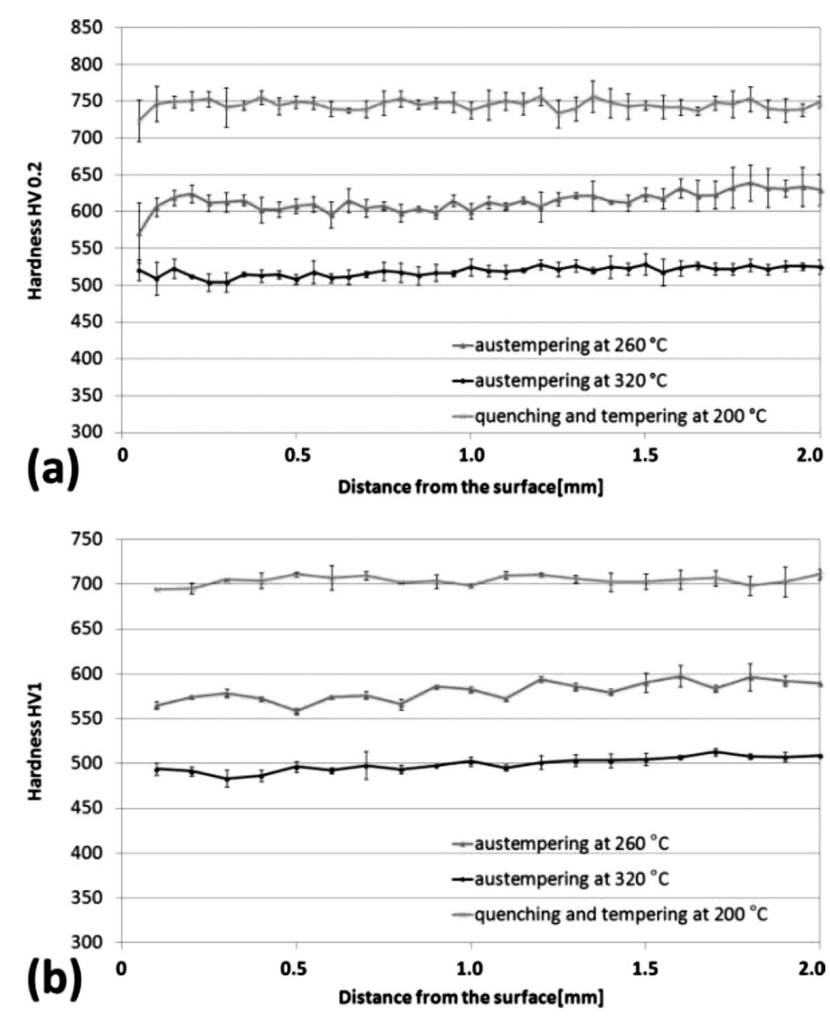

Figure 11: Hardness: a) $\mathrm{HV}_{0.2}$ and b) $\mathrm{HV}_{1}$ profiles for the carburized surface layer on 35CrSiMn5-5-4 steel after various heat treatments Slika 11: Profili trdote: a) $\mathrm{HV}_{0,2}$ in b) $\mathrm{HV}_{1}$ v naogljičeni plasti jekla 35CrSiMn5-5-4 po različnih toplotnih obdelavah

average grain size was $(152 \pm 23) \mathrm{nm}$. During the austempering at $320{ }^{\circ} \mathrm{C}$ carbide-free bainite of a submicron grain size $140 \mathrm{~nm} \pm 10 \mathrm{~nm}$ was formed in the core (Figure 9). However, a relatively large number of larger ferrite grains of about $0.5 \mu \mathrm{m}$ were also observed (Figure 10). In both cases, the relative austenite volume fraction in the core, equal to $(13 \pm 3) \%$ and $(11.4 \pm 2.3) \%$ for the austempering at $260{ }^{\circ} \mathrm{C}$ and $320{ }^{\circ} \mathrm{C}$, respectively, was significantly lower than in the carburised layer. Austenite mainly occurred in three different forms: as very thin layers $(29 \pm 4) \mathrm{nm}$ in the case of the treatment carried out at $260{ }^{\circ} \mathrm{C}$; as thicker layers $(46 \pm 6) \mathrm{nm}$; and small blocks $\left(0.086 \mu \mathrm{m}^{2}-0.288 \mu \mathrm{m}^{2}\right)$ in the case of the treatment conducted at $320{ }^{\circ} \mathrm{C}$.

In the case of the austempering at $320{ }^{\circ} \mathrm{C}$, which is higher than the $M \mathrm{~s}$ temperature, various factors may affect the structure of the core as well as the volume fractions of certain phases. The previous studies conducted on the $35 \mathrm{CrSiMn} 5-5-4$ steel revealed that the time necessary for completing the process of the bainitic transformation at $320{ }^{\circ} \mathrm{C}$ was slightly below 2 h. $^{15}$ According to the literature,,$^{20,21}$ extending the time of isothermal treatment over the critical value results in a coalescence of ferritic grains and leads to the formation of austenite in the form of blocks. The increase in the grain sizes of particular phases may be also affected by the temperature of the treatment. ${ }^{21}$ Simultaneously, the

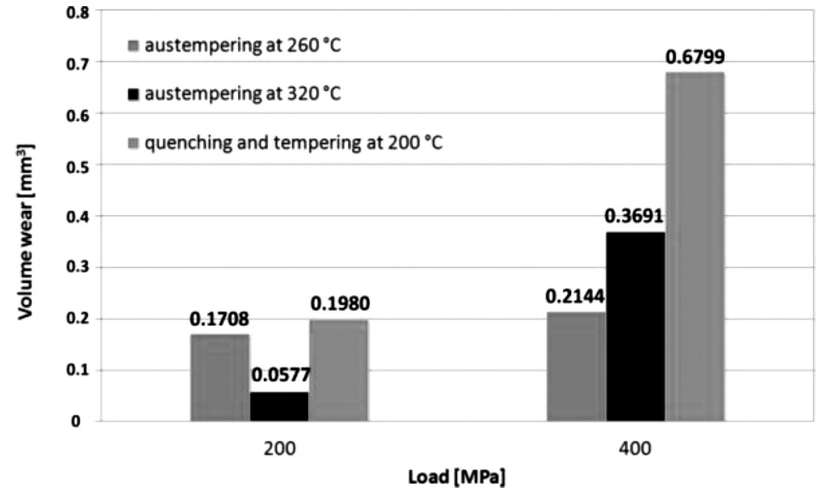

Figure 12: Volumetric wear of the carburized surface layer on 35CrSiMn5-5-4 steel after various heat treatments

Slika 12: Volumenska obraba naogljičene plasti jekla 35CrSiMn5-5-4 po različnih toplotnih obdelavah

relative volume fraction of the retained austenite has a tendency to decrease with the increase in the time of the treatment. ${ }^{20}$

The heat treatment described in the present study lasted for $24 \mathrm{~h}$. Therefore, the grain sizes of ferrite and austenite in the core increased, whereas the relative austenite volume fraction decreased during the austempering in comparison with the previous treatment of this type of steel conducted for 2 h. ${ }^{15}$

The hardness of the layers was measured at different loads. In the case of a carburised, quenched and lowtempered layer, the hardness was higher than the hardness of the carburised steel submitted to isothermal quenching at $260{ }^{\circ} \mathrm{C}$ of approximately $130 \mathrm{HV}_{0.2}$ and 125 $\mathrm{HV}_{1}$ units. It was also higher than the hardness of the steel after the treatment at $320{ }^{\circ} \mathrm{C}$ of about $225 \mathrm{HV}_{0.2}$ and $205 \mathrm{HV}_{1}$ units (Figure 11). This may be associated with a high amount of the relatively soft retained austenite in the nano-bainitic structure. The hardness does not change on the cross-section of a layer in the case of the steel subjected to the conventional treatment. After the nanostructurisation process, the hardness of the steel slightly increased when the distance from the surface increased. With the increasing distance from the surface, the grain size also increases which should result in a decrease in the hardness. However, both the carbon content and the relative austenite volume fraction in the nanobainitic structure decreased; therefore, the hardness in the core of the austempered samples is slightly higher.

The results of the investigations on the frictional wear resistance with the applied loads of $200 \mathrm{MPa}$ and $400 \mathrm{MPa}$ are presented in Figure 12. The level of the volume wear increases with an increase in the applied load. The wear tests indicate that the layer that was carburised and then austempered is characterised by a significantly higher frictional wear resistance in comparison to a much harder carburised layer, quenched and tempered in the conventional way. This difference is particularly pronounced in the case of the layer austempered at $260{ }^{\circ} \mathrm{C}$. Most likely, this is associated with the amount of 
the retained austenite in the layer with a nano-bainitic structure. Although the austenite is a relatively soft phase, it may transform into martensite under the stresses occurring during the friction due to the TRIP effect. ${ }^{9-12}$ As a result of this effect, the hardness in the contact zone would increase significantly. This, in turn, may improve the frictional-wear resistance in comparison with the samples treated in the conventional way. ${ }^{10-12}$ However, in order to prove this theory, a further study of the phase composition performed with XRD is required.

\section{CONCLUSIONS}

The austempering process conducted on the carburised 35CrSiMn5-5-4 steel allowed the formation of a nano-bainitic structure in the carburised layer as well as the formation of a martensite or carbide-free bainite structure with submicron grain sizes in the core of the examined material.

The increase in the carbon content in the layer during the carburizing favours the formation of the retained austenite, which may undergo a martensitic transformation due to the stresses during the wear test. The formed martensite may significantly increase the frictional-wear resistance of the examined steel.

Low-temperature isothermal quenching may be a new heat-treatment method applied on steel after carburisation. It is an alternative to the conventional treatment of quenching and low tempering. It seems beneficial in terms of the properties of a layer such as the increase in the frictional-wear resistance and lower quenching distortions.

\section{Acknowledgements}

The results presented in this paper were obtained within the project "Production of nanocrystalline steels using phase transformations" - NANOSTAL (contract no. POIG 01.01.02-14-100/09 made with the Polish Ministry of Science and Higher Education). The project is co-financed by the European Union from the European Regional Development Fund, within Operational Programme Innovative Economy 2007-2013.

\section{REFERENCES}

${ }^{1}$ C. Garcia-Mateo, F. G. Caballero, H. K. D. H. Bhadeshia, ISIJ International, 43 (2003) 11, 1821-1825, doi:10.2355/isijinternational. 43.1821

${ }^{2}$ F. G. Caballero, H. K. D. H. Bhadeshia, K. J. A. Mawella, D. G. Jones, P. Brown, Materials Science and Technology, 18 (2002) 3, 279-284, doi:10.1179/026708301225000725

${ }^{3}$ F. G. Caballero, H. K. D. H. Bhadeshia, Current Opinion in Solid State and Materials Science, 8 (2004) 3-4, 251-257, doi:10.1016/ j.cossms.2004.09.005

${ }^{4}$ C. Garcia-Mateo, F. G. Caballero, ISIJ International, 45 (2005) 11, 1736-1740, doi:10.2355/isijinternational.45.1736

${ }^{5}$ W. A. Świątnicki, K. Pobiedzińska, E. Skołek, A. Gołaszewski, Sz. Marciniak, Ł. Nadolny, J. Szawłowski, Materials Engineering (Inżynieria Materiałowa), 6 (2012), 524-529

${ }^{6}$ H. K. D. H. Bhadeshia, Proc. R. Soc. A, 466 (2010) 2113, 3-18, doi:10.1098/rspa.2009.0407

${ }^{7}$ H. K. D. H. Bhadeshia, Mater. Sci. Eng. A, 481-482 (2008), 36-39, doi:10.1016/j.msea.2006.11.181

${ }^{8}$ C. Garcia-Mateo, F. G. Caballero, Materials Transactions, 46 (2005) 8, 1839-1846, doi:10.2320/matertrans.46.1839

${ }^{9}$ B. Decooman, Current Opinion in Solid State and Materials Science, 8 (2004) 3-4, 285-303, doi:10.1016/j.cossms.2004.10.002

${ }^{10}$ K. Wasiluk, E. Skołek, W. A. Świątnicki, Materials Engineering (Inżynieria Materiałowa), 6 (2013), 911-915

${ }^{11}$ E. Skołek, K. Wasiak, J. Krasoń, W. A. Świątnicki, Materials Engineering (Inżynieria Materiałowa), 6 (2013), 868-871

${ }^{12}$ P. Zhang, F. C. Zhang, Z. G. Yan, T. S. Wang, L. H. Qian, Wear, 271 (2011) 5-6, 697-704, doi:10.1016/j.wear.2010.12.025

${ }^{13}$ H. K. D. H. Bhadeshia, C. Garcia-Mateo, P. Brown, Bainite steel and methods of manufacture thereof, Patent Application Publication, 2011, No US 2011/0126946 A1, available from World Wide Web: https://www.google.com.ar/patents/US20110126946

${ }^{14}$ J. Dworecka, K. Pobiedzińska, E. Jezierska, K. Rożniatowski, W. Świątnicki, Materials Engineering (Inżynieria Materiałowa), 2 (2014), 109-112

${ }^{15}$ E. Skołek, Sz. Marciniak, W. Świątnicki, Materials Engineering (Inżynieria Materiałowa), 2 (2014), 199-202

${ }^{16}$ P. Kula, J. Olejnik, P. Heilman, Hydrocarbon gas mixture for the under-pressure carburizing of steel, European Patent No.: EP1558780, 2007, United States Patent No.: US 7513958, Available from World Wide Web http://www.google.com/patents/ EP1558780A1?cl=en

${ }^{17}$ L. C. Chang, H. K. D. H. Bhadeshia, Materials Science and Technology, 11 (1995) 9, 874-881

${ }^{18}$ PN-EN ISO 6507-1:1999, Metale - Pomiar twardości sposobem Vickersa - Metoda badań, 1999

${ }^{19}$ ASTM G77-93, Standard Test Method for Ranking Resistance of Materials to Sliding Wear Using Block-on-Ring Wear Test, 1993

${ }^{20}$ C. Liu, Z. Zhao, S. D. Bhole, Materials Science and Engineering A, 434 (2006) 1, 289-293, doi:10.1016/j.msea.2006.06.078

${ }^{11}$ Y. K. Lee, H. C. Shin, Y. C. Jang, S. H. Kim, C. S. Choi, Scripta Materialia, 47 (2002) 12, 805-809, doi:10.1016/S1359-6462(02) 00303-2 